\title{
Associations between fasciolosis and milk production, and the impact of anthelmintic treatment in dairy herds
}

\author{
Kerstin Köstenberger $^{1}{ }^{\mathbb{D}} \cdot$ Alexander Tichy $^{2} \cdot$ Karl Bauer $^{3} \cdot$ Peter Pless $^{4}$. \\ Thomas Wittek ${ }^{1}$
}

Received: 3 March 2017 / Accepted: 2 May 2017 / Published online: 6 June 2017

(C) The Author(s) 2017. This article is an open access publication

\begin{abstract}
Liver fluke is a ubiquitous parasite that causes extensive production losses in cattle and is a zoonosis. The aims of this study were to determine the prevalence of fasciolosis in 178 dairy cattle herds in Styria (federal state of Austria) and its influence on production, to detect the risk factors for infection, and to explore effective strategies in management and control. A questionnaire on farm management, prophylaxis, and therapy was developed and applied. Furthermore, production parameters (milk yield, milk protein content, butter fat content, non-return rate 90 , calving to conception interval, service period) were recorded for 2014 and 2015, and a commercial ELISA for detection of Fasciola hepatica antibodies was applied in bulk tank milk in March 2014 and March 2015. Analysis of bulk tank milk samples showed a prevalence of $61.3 \%$ in 2014 and $45.5 \%$ in 2015 . No associations could be found between F. hepatica exposure and farm structure or pasture management. Farms with highly positive (optical density ratio (ODR) $\geq 0.6$ and lying above the upper interquartile range) antibody levels had a significantly lower annual milk yield of $438 \mathrm{~kg}$ per cow per year $(p=0.045)$, butterfat content of $0.091 \%(p=0.004)$, and milk protein content of $0.046 \%$ $(p=0.024)$. However, fertility parameters were not significantly associated with liver fluke exposure. Anthelmintic
\end{abstract}

Kerstin Köstenberger

k.koestenberger@gmx.at

1 University Clinic for Ruminants, University for Veterinary Medicine Vienna, Veterinärplatz 1, 1210 Vienna, Austria

2 Department for Biomedical Sciences, University for Veterinary Medicine Vienna, Veterinärplatz 1, 1210 Vienna, Austria

3 Styrian Animal Health Service (AHS), Graz, Austria

4 Department of Veterinary Administration, Styrian Government, Graz, Austria treatment led to significantly lower antibody levels in the subsequent year $(p=0.042)$ and had a significant influence on protein content in milk $(p=0.003)$. This study highlighted the importance of fasciolosis in Austria and its influence on milk production and the need for veterinary advice regarding prophylactic measures to reduce economic losses.

Keywords Fasciola hepatica · Dairy cattle · ELISA · Milk production $\cdot$ Risk factors $\cdot$ Treatment

\section{Introduction}

Fasciola hepatica is a ubiquitous parasite of cattle and sheep being found in all inhabited continents. In Europe, prevalence based on herd-level antibodies range between countries from $7 \%$ in south central Sweden (Höglund et al. 2010), 18\% in Switzerland (Rapsch et al. 2006), and 23.6\% in Germany (Kuerpick et al. 2013) to 78\% in Ireland (Selemetas et al. 2015a) and 79.7\% in Great Britain (Howell et al. 2015). For Austria, Matt et al. 2007 could show a prevalence of $73 \%$ in the federal state Tyrol. In Carinthia (federal state of Austria), a prevalence of more than $90 \%$ was reported in individual serological tests on farm level (Duscher et al. 2011).

Weather and pasture conditions are the major influences on the incidence of liver fluke infections as these control the habitat and so the population of the recognized intermediate host, the snail Galba truncatula. High rainfall intensity at the appropriate time, coupled with poorly drained loamy soils leading to oligotrophic standing waters, is risk factor for the presence of the intermediate host and therefore for the infection with F. hepatica (Bennema et al. 2011; Charlier et al. 2011; Howell et al. 2015; Selemetas et al. 2015b). Other parameters such as drinking water systems on pastures (Selemetas et al. 2015a; Charlier et al. 2011), herd sizes 
(Charlier et al. 2011; Selemetas et al. 2015a; Howell et al. 2015), and grazing season length (Bennema et al. 2011; Selemetas et al. 2015a) have been described in literature as further risk factors all leading to an increase of oligotrophic troughs where the snails can breed thus allowing rapid multiplication of the parasite.

In many cases, fasciolosis is a subclinical disease presenting with herd- or flock-level production losses rather than the classic clinical signs in individuals. In Switzerland, the nationwide costs of infection with liver fluke were estimated at $€ 52$ million, or $€ 299$ per infected animal per year (Schweizer et al. 2005).

Infection with $F$. hepatica results in decreased milk yield (Charlier et al. 2007; Khan et al. 2009; Mezo et al. 2011, Charlier et al. 2012; Howell et al. 2015). Some studies reported a decrease in butter fat content (Charlier et al. 2007; Khan et al. 2009) while others could find no evidence of this (Mezo et al. 2011; Charlier et al. 2012; Howell et al. 2015). Similarly, while some describe effects on fertility such as increased intercalving interval (Charlier et al. 2007), decreased conception rate (Oakley et al. 1979), and delay in the onset of puberty (Lopez-Diaz et al. 1998), others have not observed any differences in the reproduction parameters they studied (Mezo et al. 2011; Howell et al. 2015).

Fasciolosis has also negative effects on carcass quality at slaughter. Sanchez-Vazquez and Lewis (2013) reported lower weight and lower fat levels of carcasses from animals with liver fluke infestation. Further liver condemnation of infected animals leads to substantial visible economic losses (Schweizer et al. 2005; Radfar et al. 2015).

Vercruysse and Claerebout (2001) proposed a herd prevalence of fasciolosis equal or over $25 \%$ as a threshold for significant production losses. Strategies to prevent and treat fasciolosis have been developed to minimize these losses. Primarily, snail control must be guaranteed. Pasture management like fencing and draining of wet soils or the pasture rotation system to decrease the infection risk has been described by Boray (1971). In addition, anthelmintic treatment to reduce parasitism in the host and therefore the egg elimination and pasture contamination has been propounded (Roberts and Suhardono 1996; Boray 1971; Torgerson and Claxton 1999; Knubben-Schweizer et al. 2010). However, long milk and meat withdrawal times of most therapeutic agent treatment and prophylactic options are typically limited in dairy cows suffering from fasciolosis (Khan et al. 2009; Charlier et al. 2012).

The aims of this study were to assess the occurrence and importance of $F$. hepatica in dairy herds in Styria and to detect the risk factors for fasciolosis and its influences on production. Furthermore, it was an aim to explore which control strategies are suitable for dairy herds of this region. In Austria, approximately a quarter of the 2 million cattle were dairy cows kept on 61.000 farms with an average of 32 cattle per herd in 2015
(Statistik Austria 2015). Alpine pasture and smallholder farms are typical for Styria (federal state of Austria).

It has been hypothesized that farm management, prophylaxis, and treatment are associated with production and health parameters. Pasture management and anthelmintic treatment are supposed to lower the infection risk and lead to healthy high-performance herds.

\section{Materials and methods}

\section{Study design and population}

The study population consisted of a convenient sample of 178 dairy herds $(1.7 \%$ of Styrian cattle herds, Statistik Steiermark 2015 ) and a total number of 3.934 dairy cows (3\% of the amount of Styrian cattle and $4.8 \%$ of the Styrian dairy cow population, Statistik Steiermark 2015) with an average number of 22 dairy cows per herd. These herds were located in a district of the upper region of Styria typical of alpine farming and grazing practices. Criteria for participation were the membership in the Styrian Animal Health Service (Verein Steirischer Tiergesundheitsdienst (TGD) Graz, Austria) and in the Milk Recording Service Styria (Landeskontrollverband (LKV) Steiermark, Austria). All potentially suitable dairy herds in the area had been asked to participate by the LKV; the 178 herds joined the study voluntarily. The farmers of the herds were invited to participate in a questionnaire and gave their consent for using their milk test results and herd information regarding their production parameters for the purpose of research.

\section{Questionnaire}

The questionnaire was developed in 2015 and consisted of four parts: farm structure (A), grazing management (B), pasture hygiene management $(\mathrm{C})$, and anthelmintic treatment $(\mathrm{D})$ similar as recommended by Selemetas et al. (2015a). The 23 questions included 5 open-answer questions, 12 multiplechoice questions, and 6 binary questions. The questionnaire was conducted face to face by the corresponding author.

Section A (farm structure) determined the total amount of cattle; the number of dairy cows and young stock; the predominant breed kept on the farm; if sheep, goats, and horses shared pasture with the cattle; and if there were deer or other wild ruminants seen on the pasture.

Section B (grazing management) asked about the total area of grassland (ha), the number of paddocks, and if the cattle grazed the whole year day and night, and the whole year during the day or grazed seasonally (length in months). Furthermore, it was asked how the pasture was used (ration grazing, rotation pasture, continuous grazing, or alpine pasture) for dairy and for young stock. Farmers were asked about 
the quality of pasture drainage (good, moderate, poor), the percentage of grassland $(<10,<25,25-50,50-75,>75 \%)$ with snail habitats (streams, ponds, flooded ditches), the way drinking water was provided on the pasture (drinking bowl, trough, pond, burn, river), and if they had changed anything in their grazing management since they were informed about the antibody levels against $F$. hepatica of their farms (drainage, fencing, rotational pasture management).

Section C (pasture hygiene management) asked farmers about general hygiene management in the herd and if they had changed anything regarding the pasture hygiene since they were informed about the antibody levels against F. hepatica of their farms (e.g., not using silage or storing hay for a couple of months if the grass was harvested from moist pastures).

Section D (anthelmintic treatment) asked about treatment in general, the drug used, the dosage, if all cattle were treated and if not which were treated, and the frequency and time of use.

\section{Detection of $F$. hepatica exposure}

Bulk milk tank (BMT) samples were supplied by the Styrian Animal Health Service. After collection, BMT samples were stored for no longer than 7 days at between 2 and $4{ }^{\circ} \mathrm{C}$. The Veterinary Laboratory of TGD tested bulk tank milk samples in March 2014 and March 2015 using SANOVIR ® F. hepatica-Ab (Boehringer Ingelheim Svanova, Sweden), a commercial $F$. hepatica excretory-secretory (ES) antigen ELISA, according to Charlier et al. 2007, which is a modification of Salimi-Bejestani et al. (2005b). Antibody levels were expressed as an optical density ratio (ODR) with the formula $\mathrm{ODR}=(\mathrm{OD}-\mathrm{NC}) /(\mathrm{PC}-\mathrm{NC})$, with $\mathrm{OD}$ as the optical density of the sample and $\mathrm{NC}$ and $\mathrm{PC}$ as the $\mathrm{OD}$ of the negative and positive controls (Charlier et al. 2007). The sensitivity and specificity of this Ag-detecting ELISA to detect herds in which more than $25 \%$ of the cows are infected are $96 \%$ (95\% CI 89-100\%) and 80\% (95\% CI 66-94\%), respectively (Salimi-Bejestani et al. 2005a).

\section{Production parameters}

Milk parameters (milk yield, milk protein content, butter fat content) and fertility variables (non-return rate 90 (ratio of cows, which not get seeded again within 90 days), calving to conception interval, service period) were provided by the Milk Recording Service Styria, Austria, which is routinely recording monthly milk and fertility parameters. Data were available for all herds participating in the study during the periods October 2013-September 2014 and October 2014September 2015.
Table 1 Descriptive statistics of farm structure parameters $(n=178)$

\begin{tabular}{lllll}
\hline Variable & Minimum & Maximum & Mean & SD \\
\hline Total cattle $(n)$ & 10 & 400 & 53 & 40 \\
Dairy cattle $(n)$ & 5 & 80 & 22 & 13 \\
Young stock $(n)$ & 0 & 320 & 29 & 28 \\
Pastures/paddocks $(n)$ & 0 & 14 & 4 & 2 \\
Pasture size (ha) & 0 & 110 & 16 & 14 \\
\hline
\end{tabular}

\section{Statistical analysis}

Data were stored in Excel and imported into SPSS Statistics version 20.0. (IBM Corp., USA) for statistical analysis. Standard distribution was tested with Kolmogorov-Smirnov test. For a detailed overview, farms were divided into three groups (Charlier et al. 2012): highly positive herds or high $(\mathrm{H})$ having an ODR $\geq 0.6$ and lying above the upper interquartile range, herds having an ODR between 0.6 and 0.3 defined as slightly positive or medium (M), and herds with an ODR $<0.3$ as "negative" or low (L).

For further statistical analysis, slightly positive and negative herds were summarized in one group.

To compare the parameters, a $t$ test for independent samples was used. Influences of treatment on ODR and production parameters were calculated by variance analysis. Associations between variables were assessed calculating Pearson correlation coefficients. Results were considered significant at $p<0.05$.

Table 2 Summary of variables concerning pasture management $(n=178)$

\begin{tabular}{ll}
\hline Categorical variables & $\%$ of farms positive for variable \\
\hline Grazing management & \\
Ration grazing & 46.60 \\
Rotation pasture & 48.9 \\
Continuous grazing & 24.7 \\
Alpine farming dairy cattle & 18.5 \\
Alpine farming young cattle & 71.9 \\
Drainage of pastures & \\
Good drainage & 72.2 \\
Moderate drainage & 26.7 \\
Poor drainage & 1.1 \\
Supply of water on pastures & \\
Drinking bowl & 38.9 \\
Trough & 60.6 \\
Pond, stream, river & 52.6 \\
\hline
\end{tabular}


Table 3 Influence of highly positive ODR values $(\geq 0.6)$ on production parameters; highly positive farms $(n=40)$, slightly positive/negative farms $(n=138)$. NRR90 non-return rate $90, C C I$ calving to conception interval, $S P$ service period

\begin{tabular}{llllll}
\hline Variable & $\begin{array}{l}\text { Highly positive farms } \\
\text { mean }\end{array}$ & $\begin{array}{l}\text { Slightly positive/negative } \\
\text { farms mean }\end{array}$ & $t$ & $p$ value & $\begin{array}{l}\text { Mean } \\
\text { difference }\end{array}$ \\
\hline Milk yield (kg/year) & 6981.4 & 7419.412 & 2.009 & 0.045 & 438.012 \\
Butter fat (\%) & 4.1 & 4.192 & 2.919 & 0.004 & 0.091 \\
Protein (\%) & 3.403 & 3.449 & 2.266 & 0.024 & 0.046 \\
NRR90 & 65.23 & 63.883 & -0.602 & 0.548 & -1.347 \\
CCI & 396.037 & 390.01 & -1.291 & 0.198 & -6.027 \\
SP & 107.027 & 100.197 & -1.539 & 0.125 & -6.83 \\
\hline
\end{tabular}

\section{Results}

\section{Prevalence of $\boldsymbol{F}$. hepatica}

During the 2 years of the study, a general decrease of ODR (ODR $2014=0.408$, median 0.372, IQR 0.34; ODR $2015=0.341$, median 0.274 , IQR $0.32 ; p<0.001)$ was observed. In 2014, the overall total herd prevalence of fluke infection was $61.3 \%$ (109 of 178 herds) which could be subdivided in $22.5 \%$ (40 herds) highly positive and $38.8 \%$ (69 herds) slightly positive herds. In 2015, the overall herd prevalence was $45.5 \%$ ( 81 of 178 herds) divided in $16.3 \%$ (29 herds) highly positive and $29.2 \%$ (52 herds) slightly positive herds.

\section{Farm structure and pasture management as risk factors}

The questionnaire resulted in the following results: on average, the farms had 53 cattle in total, (22 dairy cattle and 30 young stock), 4 set pastures or paddocks, and an overall pasture area of 16 ha. Detailed information is shown in Table 1.

Simmental was the predominant breed with $92.1 \%$. Only $6.2 \%$ of all the farms kept other animals than cattle on their pastures. In $88.8 \%$, paddocks were used seasonally (rarely or not during winter). The season lasted around 6 months on average $(\overline{\mathrm{x}} 6.192 ; \sigma 1.319)$ depending on the geographical location of the farm. The remaining results are shown in Table 2.

None of the variables on farm structure or pasture management were significantly correlating with ODR values.

\section{Influence on milk production and fertility}

Parameters describing milk production were negatively correlated with ODR values: milk yield $(\mathrm{kg})(r=-0.211$, $p<0.001)$, butterfat $(\%)(r=-0.235, p<0.001)$, and milk protein $(\%)(r=-0.256, p<0.001)$. Highly positive herds showing an ODR over the interquartile range had significantly lower milk yield, butterfat content, and milk protein content. Compared to slightly positive or negative farms, there was a decrease in annual milk yield of $438 \mathrm{~kg}$, or $6 \%$ (measured on the mean milk yield) per cow per day $(p=0.045)$. Furthermore, a decrease in butterfat of $0.091 \%(p=0.004)$ and in milk protein of $0.046 \%(p=0.024)$ in highly positive herds was found. Service period, calving to conception interval, and the $90 \%$ non-return rate did not show any significant changes. A summary of the data is shown in Table 3.

\section{Effect of anthelmintic treatment}

A total of 50 farmers (28\%) treated their herds with an anthelmintic drug supposedly effective against trematodes after they

Table 4 Influence of treatment on ODR values $(n=178)$

\begin{tabular}{|c|c|c|c|c|c|c|c|c|}
\hline & \multirow[b]{2}{*}{$n$} & \multicolumn{3}{|c|}{ ODR 2014} & \multicolumn{3}{|c|}{ ODR 2015} & \multirow{2}{*}{$\begin{array}{l}\text { Percentage of farms with } \\
\text { decrease in ODR }(\%)\end{array}$} \\
\hline & & Median & $25 \%$ percentile & $75 \%$ percentile & Median & $25 \%$ percentile & $75 \%$ percentile & \\
\hline \multicolumn{9}{|l|}{ Treated } \\
\hline $\mathrm{ODR} \geq 0.6$ & 23 & 0.689 & 0.666 & 0.749 & 0.528 & 0.408 & 0.618 & 95.7 \\
\hline ODR $0.3-0.6$ & 21 & 0.498 & 0.404 & 0.548 & 0.403 & 0.315 & 0.510 & 57.1 \\
\hline ODR $<0.3$ & 6 & 0.222 & 0.170 & 0.270 & 0.121 & 0.083 & 0.183 & 66.7 \\
\hline \multicolumn{9}{|l|}{ Not treated } \\
\hline ODR $\geq 0.6$ & 17 & 0.696 & 0.634 & 0.752 & 0.643 & 0.525 & 0.833 & 58.8 \\
\hline ODR $0.3-0.6$ & 48 & 0.411 & 0.352 & 0.485 & 0.288 & 0.202 & 0.435 & 77.1 \\
\hline ODR $<0.3$ & 63 & 0.200 & 0.161 & 0.260 & 0.182 & 0.125 & 0.241 & 63.5 \\
\hline
\end{tabular}


Table 5 Influence of treatment on production parameters, farms with ODR $\geq 0.6$ and treated $n=23$

\begin{tabular}{llllll}
\hline & Variable & Mean & Minimum & Maximum & SD \\
\hline Before treatment (2014) & ODR & 0.698 & 0.6 & 0.808 & 0.054 \\
& Milk yield (kg) & 7172.167 & 4102.204 & $11,082.08$ & 1859.365 \\
& Protein (\%) & 3.422 & 3.14 & 3.65 & 0.16 \\
& Butter fat (\%) & 4.136 & 3.57 & 4.6 & 0.243 \\
After treatment (2015) & ODR & 0.508 & 0.121 & 0.775 & 0.158 \\
& Milk yield (kg) & 7112.212 & 4019.496 & $12,302.436$ & 1957.33 \\
& Protein (\%) & 3.408 & 3.13 & 3.63 & 0.142 \\
& Butter fat (\%) & 4.079 & 3.59 & 4.58 & 0.259 \\
\hline
\end{tabular}

had been informed about their herds having high ODR values. Most of these herds (93.8\%) were treated with a combination of closantel and ivermectin pour on (Closamectin $®$, Norbrook Laboratories Limited, Great Britain). All farmers stated that they applied $10 \mathrm{ml} / 100 \mathrm{~kg}$ body weight, as recommended by the manufacturer. The second drug used was albendazol (Valbazen ${ }^{\circledR}$, Zoetis, Austria, Albendazol-ani-medica ${ }^{\circledR}$, Animedica, Germany), applied as oral suspension $4 \mathrm{ml} /$ $10 \mathrm{~kg}$ body weight (Valbazen ${ }^{\circledR}$ ) or $10 \mathrm{ml} / 100 \mathrm{~kg}$ body weight (Albendazol-ani-medica®). Dairy cattle were treated at drying off whereas young stock was treated before and/or after grazing on pasture. The treatment of herds which had ODR values $\geq 0.6$ resulted in a significant decrease of ODR values (ODR $2014=0.698 ;$ ODR $2015=0.508 ; F(1,38)=4.41 ; p=0.042)$. There was no significant effect of treatment of herds with ODR values $<0.6(F(1136)<1 ; p=0.768)$. Detailed information is shown in Table 4 . Treatment showed also a significant influence on protein content in the milk. Content of protein could be held on a significantly higher level if herds were treated where necessary (ODR $\geq 0.6$ ), whereas it was constantly decreasing in herds that were not treated $(F(1,38)=10.092 ; p=0.003)$. However, treatment did not result in significant influence on milk yield $(F(1,38)<1$; $p=0.437)$ and butterfat content $(F(1,8)<1 ; p=0.657)$ of the subsequent year. Detailed information is provided in Tables 5 and 6.

Table 6 Influence of treatment on protein content (\%) in milk, farms with ODR $\geq 0.6$, farms treated $n=23$, farms without treatment $n=17$

\begin{tabular}{lllll}
\hline Variable & \multicolumn{1}{c}{ Mean } & Minimum & Maximum & SD \\
\hline $\begin{array}{l}\text { Protein (\%) } \\
2014\end{array}$ & 3.422 & 3.14 & 3.65 & \\
2015 & 3.408 & 3.13 & 3.63 & 0.16 \\
Protein (\%) & without treatment & & 0.142 \\
2014 & 3.401 & 3.15 & 3.62 & 0.131 \\
2015 & 3.303 & 3.08 & 3.6 & 0.142 \\
\hline
\end{tabular}

\section{Discussion}

The ELISA testing of the BTM samples showed an exposure of the dairy herds of $61.3 \%$ in 2014 and of $45.5 \%$ in 2015 based on the $\mathrm{H}$ (high) and $\mathrm{M}$ (medium) criteria (as explained in "Material and methods" section). Comparisons with other studies are difficult to draw since cut-off levels differ between ELISA results. Duscher et al. (2011) showed a prevalence of $60 \%$, found by bulk milk ELISA on herd level over more than 1 year in Carinthia (federal state of Austria). These results differ from those found in Ireland (78\%) by Selemetas et al. (2015a) and in Great Britain $(79.9 \%$ ) by Howell et al. (2015). The reason may either be the different environmental and climatic conditions or that the samples in the present study were collected in March and the others in October to December (Howell et al. 2015; Selemetas et al. 2015a). Since due to pasture contamination the peak of the annual life cycle of $F$. hepatica is expected at the end of the summer (SalimiBejestani et al. 2005a), the antibody levels would be higher in autumn.

No influence of small ruminants, horses, or deer sharing pastures with cattle on antibody levels was found although they are potential hosts for liver fluke. However, the percentage of farmers keeping horses and small ruminants together with cattle in this study was very low $(6.2 \%)$ so the importance of these species remains open. Alpine farming in Austria leads to high incidence of deer on the pastures. In this study, nearly $90 \%$ of all farmers confirmed deer sightings on their pastures. Therefore, it was not possible to assess the influence of wildlife on bovine fasciolosis.

Although the impact of poorly drained, loamy pasture, high rainfall, and flooded parts of the soil on the incidence of fasciolosis is known (Bennema et al. 2011; Charlier et al. 2011; Howell et al. 2015), the current study could not show higher risk of farms on which the farmers stated that they have poorly drained or boggy pastures. The explanation could be that some farmers may have wrongly assessed the status of their pasture or were unwilling to give the correct answer. Only $1.1 \%$ of the farmers confirmed having poor drainage 
status on their pastures, whereas $72.2 \%$ valued their pastures having a good drainage status.

The present study showed a reduction of milk yield of around $6 \%$ (438 kg/cow/year) between $\mathrm{H}$ and $\mathrm{M} / \mathrm{L}$ herds. Several other studies reported an association between liver fluke infection and losses in milk yield with similar results (Charlier et al. 2007; Khan et al. 2009; Mezo et al. 2011; Charlier et al. 2012). However Howell et al. (2015) showed a reduction of $15 \%$ in milk yield (based on 32 herds with similar results in 475 herds where milk yield was not measured but estimated), probably because of the high prevalence found in this study.

In 2015 , the average milk price was $€ 0.34$ per kg (Agrar Markt Austria 2015); thus, a reduction in annual milk yield of $438 \mathrm{~kg}$ results in a financial loss of $€ 147.96$ per cow per year, resulting in a loss of $€ 3255.12$ on herd level (measured on the mean dairy herd size of this study of 22 cows). Possible additional losses of body condition are not considered as this was not measured.

Fluke infection had a significant effect on the content of butterfat and milk protein in the current study. Some previous studies (Charlier et al. 2007; Khan et al. 2009) found similar associations for butterfat, but protein content effects were inconsistent (Charlier et al. 2007; Mezo et al. 2011; Charlier et al. 2012; Howell et al. 2015). Changes in these parameters might be more obvious in the current study, since the predominant study breed was Simmental, a breed with naturally high milk butterfat and protein. Like Mezo et al. (2011) and Howell et al. (2015), no associations between high antibody levels and fertility parameters were found, although others have found an effect (Oakley et al. 1979; Lopez-Diaz et al. 1998; Charlier et al. 2007).

Treatment showed effect on antibody levels and on milk protein in highly positive herd content in the current study. There were no influences on milk yield and butterfat. Former studies reported a decrease of ODR values (Charlier et al. 2012) and increases of milk yield (Khan et al. 2009; Charlier et al. 2012) and butterfat (Khan et al. 2009) after treatment on individual cow level. Comparison is limited with Charlier et al. (2012) since this study only found changes of milk yield in herds with ODR of $0.3-0.5$ and not $\geq 0.5$. The current study worked with values of ODR $\geq 0.6$.

Overall, this study showed that fasciolosis does have an impact on production and that treatment can lower the burden. Comparison between the financial loss of well over $€ 100$ per cow/year in $\mathrm{H}$ herds and the treatment costs of around $€ 35$ per cow/year indicates the value of such treatment not only for the economic reason but also for the healthiness of the herds. We suggest the same follows for $\mathrm{M}$ herds. It has to be considered that this study was only over 1 year and the long-term effects of such targeted annual treatments in lowering challenge may well be cumulative.
Acknowledgements Open access funding provided by University of Veterinary Medicine Vienna. The authors thank the farmers for participation in this study. Furthermore, we thank the Milk Recording Service Styria (Landeskontrollverband LKV Steiermark) for providing milk production data.

Open Access This article is distributed under the terms of the Creative Commons Attribution 4.0 International License (http:// creativecommons.org/licenses/by/4.0/), which permits unrestricted use, distribution, and reproduction in any medium, provided you give appropriate credit to the original author(s) and the source, provide a link to the Creative Commons license, and indicate if changes were made.

\section{References}

Agrar Markt Austria (2015) Assessed 2016-04-22, 09.07 am https:// www.ama.at/getattachment/8ac57894-1613-412b-a5b7890003b6a3e3/110_Erzeugermilchpreis_Jahresubersicht_20052015.pdf

Bennema SC, Ducheyne E, Vercruysse J, Claerebout E, Hendrickx G, Charlier J (2011) Relative importance of management, meteorological and environmental factors in the spatial distribution of Fasciola hepatica in dairy cattle in a temperate climate zone. Int J Parasitol 41:225-233

Boray JC (1971) Fortschritte in der Bekämpfung der Fasciolose. Schweiz Arch Tierheilkd 113:361-386

Charlier J, Duchateau L, Claerebout E, Williams D, Vercruysse J (2007) Associations between anti-Fasciola hepatica antibody levels in bulk-tank milk samples and production parameters in dairy herds. Prev Vet Med 78:57-66

Charlier J, Bennema SC, Caron Y, Counotte M, Ducheyne E, Hendrickx G, Vercruysse J (2011) Towards assessing fine-scale indicators for the spatial transmission risk of Fasciola hepatica in cattle. Geospat Health 5:239-245

Charlier J, Hostens M, Jacobs J, Van Ranst B, Durchateau L, Vercruysse J (2012) Integrating fasciolosis control in the dry cow management: the effect of closantel treatment on milk production. PLoS One 7(8): e43216

Duscher R, Duscher G, Hofer J, Tichy A, Prosl H, Joachim A (2011) Fasciola hepatica - monitoring the milky way? The use of tank milk for liver fluke monitoring in dairy herds as base for treatment strategies. Vet Parasitol 178:273-278

Höglund J, Dahlström F, Engström A, Hessle A, Jakubek EB, Schnieder T, Strube C, Sollenberg S (2010) Antibodies to major pasture borne helminth infections in bulk-tank milk samples from organic and nearby conventional dairy herds in south-central Sweden. Vet Parasitol 171:293-299

Howell A, Baylis M, Smith R, Pinchbeck G, Williams D (2015) Epidemiology and impact of Fasciola hepatica exposure in highyielding dairy herds. Prev Vet Med 121:41-48

Khan MK, Sajid MS, Khan MN, Iqbal Z, Iqbal MU (2009) Bovine fasciolosis: prevalence, effects of treatment on productivity and cost benefit analysis in five districts of Punjab. Pakistan Res Vet Sci 87: $70-75$

Knubben-Schweizer G, Rüegg S, Torgerson PR, Rapsch C, Grimm F, Hässig M, Deplazes P, Braun U (2010) Control of bovine fasciolosis in dairy cattle in Switzerland with emphasis on pasture management. Brit Vet J 186:188-191

Kuerpick B, Conraths FJ, Staubach C, Fröhlich A, Schnieder T, Strube C (2013) Seroprevalence and GIS-supported risk factor analysis of Fasciola hepatica infections in dairy herds in Germany. Parasitology 140(8):1051-1060

Lopez-Diaz MC, Carro MC, Cadorniga C, Diez-Banos P, Mezo M (1998) Puberty and serum concentrations of ovarian steroids during 
prepuberal period in Friesian heifers artificially infected with Fasciola hepatica. Theriogenology 50:587-593

Matt M, Schöpf K, Mader C (2007) Leberegelmonitoring: flächendeckende serologische Untersuchungen zum Fasciola hepatica- Befall in Tirol. Wien Tierärztl Mschr 94:210-213

Mezo M, González-Warleta M, Castro-Hermida JA, Muino L, Ubeira FM (2011) Association between anti-F. hepatica antibody levels in milk and production losses in dairy cows. Vet Parasitol 180:237-242

Oakley GA, Owen B, Knapp NHH (1979) Production effects of subclinical liver fluke infection in growing dairy heifers. Vet Rec 104:503507

Radfar MH, Nourollahi-Fard SR, Mohammadyari N (2015) Bovine fasciolosis: prevalence, relationship between faecal egg count and worm burden and its economic impact due to liver condemnation at Rudsar abattoir, Northern Iran. J Parasit Dis 39(3):522-525

Rapsch C, Schweizer G, Grimm F, Kohler L, Bauer C, Deplazes P, Braun U, Torgerson PR (2006) Estimating the true prevalence of Fasciola hepatica in cattle slaughtered in Switzerland in the absence of an absolute diagnostic test. Int J Parasitol 36:1153-1158

Roberts, Suhardono JA (1996) Approaches to the control of fasciolosis in ruminants. Int J Parasitol 26:971-981

Salimi-Bejestani MR, Daniel RG, Feldtead SM, Cripps PJ, Mahmoody H, Williams DJL (2005a) Prevalence of Fasciola hepatica in dairy herds in England and Wales measured with an ELISA applied to bulk-tank milk. Vet Rec 156:729-731

Salimi-Bejestani MR, McGarry JW, Felstead S, Ortiz P, Akca A, Williams DJL (2005b) Development of an antibody-detection
ELISA for Facsiola hepatica and its evaluation against a commercially available test. Res Vet Sci 78:177-181

Sanchez-Vazquez MJ, Lewis FI (2013) Investigating the impact of fasciolosis on cattle carcase performance. Vet Parasitol 193:307-311

Schweizer G, Braun U, Deplazes P, Torgerson PR (2005) Estimating the financial losses due to bovine fasciolosis in Switzerland. Vet Rec 157:188-193

Selemetas N, Phelan P, OKiely P, DeWaal T (2015a) The effects of farm management practices on liver fluke prevalence and the current internal parasite control measures employed on Irish dairy farms. Vet Parasitol 207:228-240

Selemetas N, Phelan P, OKiely P, De Waal T (2015b) Cluster analysis of fasciolosis in dairy cow herds in Munster province of Ireland and detection of major climatic and environmental predictors of the exposure risk. Geospat Health 9:271-279

Statistik Austria 2015 assessed 2016-04-05, 09.21 am http://www. statistik.at/web_de/statistiken/wirtschaft/land_und_forstwirtschaft/ viehbestand_tierische_erzeugung $/ \mathrm{milch} / \mathrm{index} . \mathrm{html}$

Statistik Steiermark,2015. Assessed 2016-06-29, 9.56 am http://www. statistik.steiermark.at/cms/dokumente/11682776_103036101/ 56b9550f/8-Viehbestand\%2015.pdf

Torgerson P, Claxton J (1999) Epidemiology and control. In: Dalton JP (ed) Fasciolosis. CABI Publishing, Wallingford, pp $113-149$

Vercruysse J, Claerebout E (2001) Treatment vs non- treatment of helminth infections in cattle: defining the threshold. Vet Parasitol 98: 195-214 